\title{
COMMENTS
}

\section{STOP PAYMENT: AN AILING SERVICE TO THE BUSINESS COMMUNITY}

One hundred forty years ago, when checks played a less important role in men's affairs, Lord Ellenborough announced ${ }^{1}$ that a stop payment order transforms a check into a "piece of waste paper," as far as the drawee bank is concerned. ${ }^{2}$ On its face, Lord Ellenborough's rule has meant that a banker who inadvertently pays a stopped check can do little more than regret his mistake. ${ }^{3}$ In today's economy, checks far exceed in volume all other forms of "money,"4 and bankers are striving to get out from under the risks imposed by the rule. But, in accomplishing their objective, the banks may come close to eliminating altogether the depositor's valued right to stop payment. This note will critically survey the present law and some proposed changes, with an eye in particular on the handiwork of the drafters of the Uniform Commercial Code. ${ }^{5}$

I

The operational effects of the present stop payment rules are clear. A bank receiving a depositor's timely stop order is not authorized to pay the stopped

I Wienholt v. Spitta, 3 Camp. 376 (1813).

2 For a discussion of the early British and American cases on "countermand," see 1 Morse, Banks and Banking $\& 398$ (6th ed., 1928), and Chalmers, Bills of Exchange $\$ 75$ (10th ed., 1932). And see note 6 infra.

${ }^{3}$ In practice, of course, the banker is doubtless often able to settle with the depositor on terms more favorable than might be had in the courts. For example, it can be supposed that many depositors might be willing to assign to the bank any rights they have in the deal in which the check was given, and that in certain cases the bank will ask that this be done. In the case of a legal showdown, however, there is little support in the stop payment cases for the position that the bank can so insist. See note 21 infra.

4 The average volume of demand deposits throughout 1952 approached $\$ 110$ billions. The average volume of currency, including Federal Reserve notes, was less than $\$ 29$ billions. But this is half the picture, or less. The average turnover of demand deposits was around twenty; the comparable velocity frgure for currency is much harder to determine with accuracy. See 38(2) Fed. Res. Bull. 1, 299, 1,301 (1952). No accurate estimates are available of the number of different checks cleared by the banks in the year: there were doubtless tens of billions of them. A typical bank might have ten to several hundred autstanding stop orders.

5 The final version of the proposed Code, American Law Institute, National Conference of Commissioners on Uniform State Laws, Uniform Commercial Code: Official Draft (text and comments ed., 1952), is hereinafter cited by section numbers and as UCC.

For general discussions of the Code, and Articles 3 and 4 in particular, see Beutel, The Proposed Uniform(?) Commercial Code Should Not Be Adopted, 61 Yale L.J. 334 (1952); Gilmore, The Uniform Commercial Code: A Reply to Professor Beutel, 61 Yale L.J. 364 (1952); Tisdale, Uniform Commercial Code-Commercial Paper, 26 N.D. Bar Briefs 252 (1950) and 27 N.D.L. Rev. 383 (1951); Beutel, Comparison of the Proposed Commercial Code, Article 3, and the Negotiable Instruments Law, $30 \mathrm{Neb}$. L. Rev. 531 (1951), and Palmer, Negotiable Instruments under the U.C.C., 48 Mich. L. Rev. 255 (1950).

A discussion of stop payment is undertaken in Stop Payment and the Uniform Commercial Code, 28 Ind. L.J. 95 (1952). And consult, generally, Horner, The Stop Payment Order, 2 Baylor L. Rev. 275 (1950). 
check and cannot charge his account if it mistakenly does. ${ }^{6}$ To avoid the possibility of loss, the bank must assure itself that each of the items it pays is not a stopped instrument, assuming the risk of a slip-up in its routine.

The drawer may stop payment for any reason that he likes-presumably, in most cases, because of fraud or failure of consideration in the transaction in which the check was given, or because the instrument itself is lost, strayed, or stolen. If stop payment were not available, the check would be paid in the normal course, and, to recover, the injured depositor would need to locate and obtain jurisdiction over the holder ${ }^{7}$-shady payees are forever absconding with the cash-and bring suit on the underlying transaction, assuming the burdens of litigation and execution of judgment. Stop payment turns the tables-secures the status quo as to the drawer and makes resort to the courts unlikely if his reasons for stopping payment are legally sufficient. Such effective control over renegade checks yields clear social benefits-it may be of critical assistance to a distressed depositor when no other help is available, it reduces litigation between depositors and payees, and it deters some forms of fraud and other commercial malpractices by payees. ${ }^{8}$ The loss of such benefits is the social cost when the stop payment machinery fails.

The "real" cost of the stop payment operation is the value of resources, primarily labor, expended in the mechanics of stopping checks. The "money" cost, borne initially by the banks, includes not only the cost of the additional effort but also an actuarial cost arising from the risk of paying the check without recourse. The extra, noneconomic cost is the legal sanction imposed for failure,

6 In Florence Mining Co. v. Brown, 124 U.S. 385, 391 (1888), the Court said: "A check upon the bank in the usual form, not accepted or certified by its cashier to be good, does not constitute a transfer of any money to the credit of the holder; it is simply an order which may be countermanded, and payment forbidden by the drawer at any time before it is actually cashed."

In German Nat. Bank v. Farmers' Deposit Nat. Bank, 118 Pa. St. 294, 313, 12 Atl. 303, 305 (1888) a clear statement of the rule was made: "I presume no one at this day questions the right of the drawer of a check to stop payment thereof. . . If the bank pays after such notice, it does so at its peril." At 5A Michie, Banks and Banking $\$ 193$ n. 45 (rev. ed., 1950) are cited cases in which the rule appears, representing twenty-four states.

Throughout this note, reference made to checks will include notes and acceptances payable at a bank, for which the rules as to stop payment are the same. 3 Paton, Dig. Leg. Op. 3485 (1944). But cf. Fiss Corp. v. National Safety Bank and Trust Co. of N.Y., 77 N.Y.S. 2d 293 (1948). See, generally, Steffen, Instruments "Payable at" a Bank, 18 Univ. Chi. L. Rev. 55 (1950).

${ }^{7}$ When a check has been fraudulently obtained, and the defrauding party retains an account in the payee bank, the problem of the bank's liability for failure to stop payment blends into that of the broader responsibility of a bank not to pay out deposits after notice of an adverse legal claim. See, generally, Michie, op. cit. supra note 6 , at $\S 88$, and cases there cited.

${ }^{8}$ There is another side to stop payment, however; it is sometimes the case that the drawer who stops payment is the wrongdoer. The payee may have carried out his end of the bargain only to find that the drawer has stopped payment on his check solely to harass or to evade payment of the amount owed. In electing not to give checks the effect of an assignment of funds, those responsible for Section 189 of the NIL may have concluded that such eventualities are not of sufficient commercial significance to warrant selection of the alternative treatment. See note 12 infra. 
and serves to put teeth into the duty. It is the risk of severe legal penalty, rather than the expense of the service itself, to which bankers say they object. ${ }^{9}$

Elementary applications of welfare economics principles would suggest that the optimum effect of stop payment is achieved when the value of its social benefits, in the marginal case, is equal to the real costs. ${ }^{10} \mathrm{~A}$ tendency toward automatic equilibrium can be built into the stop payment operation if the bank, whose diligence alone can fend off the burden resulting from failure of stop payment, is made fully to bear that burden if it erroneously pays. Acting rationally, it will then incur costs in attempting to stop payment up to the point where the marginal costs are thought to be equal in amount to the attributable reduction of risk of bearing the burden of failure. On reaching the optimum level of stop payment activity, the bank will, of course, be able to reduce unpredicatable losses to predictable expenses by insuring, and pass the cost of the service on to its depositors generally and, in some part, by fee, specifically to those who have occasion to use the service. ${ }^{11}$

From this analysis, two propositions can be deduced. (1) The banks should be required to continue to bear their long-established duty to render stop payment services. "Due care" or "good faith" as criteria for a bank's liability in case of failure can only make uncertain the proper solution of the cost-minimizing, welfare-maximizing equation. (2) The legal sanction for failure should be no more and no less than the social cost which the machinery is set up to avoidthat of locating and bringing suit against the person whose claim to the money paid him is not good. A greater sanction increases the real cost of stop payment by causing the bank to overexpend resources to avoid the greater loss, and depositors to overuse the stop payment machinery for speculative reasons. Further, it makes stop payment a greater expense to the bank and the feepaying customer than it need be, and raises the possibility of unjust enrichment of occasional depositors.

Against these criteria the present law and alternative proposals will be measured.

II

The rules of stop payment may choose among a wide range of levels of duty and sanctions in implementing public policy. At one extreme, imposing no duty

' Laws Can Reduce Stop Payment Work, 64 Bankers' Monthly 331 (1947). This is not surprising, for the scanning of checks necessary to stopping payment is ordinary procedure which is necessary, in large part, in connection with checking for such other things as forgery, alterations, correct and complete signatures, and adequacy of funds on deposit. For an account of stop payment procedures followed in a number of banks studied in Philadelphia, see Moore et al., Legal and Institutional Methods Applied to Orders to Stop Payment of Checks-II. Institutional Method, 42 Yale L.J. 1198 (1933).

${ }^{10}$ See, for a statement of the fundamental theory, Pigou, The Economics of Welfare, c. 2 (1920). The problem of the instant analysis is simplified because of the identity in this case of private and social costs, and the method of bringing private costs and social benefits into marginal equality. Other essential technical conditions here appear to be satisfied.

"Stop payment fees of varying amounts are now generally charged by banks. See Wilson, Eight Ways to Ease the Load of Handling Stop Payments, 64 Bankers' Monthly 548 (1947). 
and no sanction would give the banker complete freedom to honor a stop payment order, or not, as he might decide, with or without a charge for the service. At the other extreme might be criminal sancticns. Within the range of likely possibilities, courts and writers have considered three alternative levels of duty: (1) not willfully or intentionally to disregard the order, (2) to exercise due care, and (3) the absolute duty of "strict liability." Failure to meet any such standard of duty might call forth either of two suggested sanctions: liability only for the actual damage to the depositor, or liability for the full face amount of the paid instrument whether or not the depositor has suffered loss.

Decisions under the Negotiable Instruments Law, following the common law, place upon the banker the most severe combination-strict liability for the full amount of the stopped check. ${ }^{12}$ This result is most often said to follow from a debtor-creditor relationship between the bank and the customer. ${ }^{13}$ In accepting a checking account, the bank agrees to honor checks drawn upon it to the amount of the indebtedness. A check is an order. Orders may be revoked until acted upon. Therefore, an implied term of the deposit contract must be the right of revocation, or stopping payment, and any payment made by the bank over a timely stop order is unauthorized. ${ }^{14}$ Liability for payment on "a piece of waste

${ }^{12}$ Sections 62 and 189 of the NIL are involved.

Section 62: "The acceptor by accepting the instrument engages that he will pay it according to the tenor of his acceptance; and admits: (1) The existence of the drawer, the genuineness of his signature, and his capacity and authority to draw the instrument; and (2)The existence of the payee and his then capacity to endorse." The majority interpretation finds the doctrine of Price v. Neal, 3 Burr. 1354 (1762), adopted by this section, and applicable to cases of "payment" as well as "acceptance." See cases cited in Brannan, Negotiable Instruments Law $\$ 62$, at $905-6$ (7th ed., Beutel, 1948). This doctrine bars recovery back from the person paid on the basis of mistake of fact as to, among other things, authority granted by the drawer. It holds the bank "bound to know" the state of the drawer's account, including stop payment orders outstanding. And see note 22 infra.

Section 189: "A check of itself does not operate as an assignment of any part of the funds to the credit of the drawer with the bank, and the bank is not liable to the holder, unless and until it accepts or certifies the check." Since a check is not an assignment of the drawer's funds, the bank is liable to him for paying it in disregard of a countermand. Cases are cited at Brannan, op. cit. supra this note, at 1316. But a check may act as an assignment when it appears that this is the intention of the parties, and in such a case a stop order should have no effect after the check is taken by a bona fide purchaser for value. Green v. Brown, $22 \mathrm{~S}$.W. 2d 701 (Tex. Civ. App., 1929). See also Fourth Street Nat. Bank v. Yardley, 165 U.S. 634 (1897). Before the NIL, all checks acted as assignments in several jurisdictions: Idaho, Kaesemeyer v. Smith, 22 Ida. 1, 123 Pac. 943 (1942); Illinois, Chicago B. \& Q.R. Co. v. Merchants, Nat. Bank, 203 Ill. App. 561 (1916); Iowa, Leach v. Mechanics' Savings Bank, 202 Iowa 899, 211 N.W. 506 (1926); Kentucky, Boswell v. Citizens' Savings Bank, 123 Ky. 485, 96 S.W. 797 (1906); Louisiana, M. Feitel House Wrecking Co. v. Citizens' Bank, 159 La. 752, 106 So. 292 (1925); Nebraska, Superior Nat. Bank v. National Bank of Commerce, 99 Neb. 833, 157 N.W. 1023 (1916); Massachusetts, Universal Supply Co. v. Hildreth, 287 Mass. 538, 192 N.E. 23 (1934); South Carolina, Peurifoy v. First Nat. Bank of Batesburg, 141 S.C. 370, 139 S.E. 793 (1927); South Dakota, Turner v. Hot Springs Nat. Bank, 18 S.D. 498, 101 N.W. 348 (1904); and Wisconsin, In re Thornton's Guardianship, 243 Wis. 332, 10 N.W. 2d 193 (1943).

${ }^{13}$ See, e.g., In re Thornton's Guardianship, 243 Wis. 332, 10 N.W. 2d 193 (1943); Funt v. Security State Bank, 91 Ore. 352, 179 Pac. 248 (1919).

14 Most of the litigation on stop orders deals with their "timeliness" and adequacy of "form." To be effective a stop order must describe the check with reasonable accuracy, John H. Mahon Co. v. Huntington Nat. Bank of Columbus, 62 Ohio App. 261, 23 N.E. 2 d 638 
paper" cannot be avoided by showing good faith or due care..$^{15}$

A logical consequence of the contract theory of stop payment is that a depositor may withdraw authorization for any reason that strikes his fancy, just as an offer can be revoked at any time before it is acted upon. ${ }^{16}$ But stopping payment cannot affect the liability of the drawer on the instrument or on

(1939), and must be in the hands of the payee bank before it has paid or accepted the check. Steiner v. Germantown Trust Co., 104 Pa. Super. 38, 158 Atl. 180 (1932), discussed in Moore, op. cit. supra note 9 . The moment at which a check is "paid" is not clear, but has been held to be at the time when drawer's account is charged. Nineteenth Ward Bank v. First Nat. Bank of South Weymouth, 184 Mass. 49, 67 N.E. 670 (1903). But a recent decision holds that payment is not made except by "actual payment either in cash or by a substitute accepted unconditionally by the payee," thus, that posting to the drawer's account and mailing a remittance to the clearance house bank is not sufficient to foreclose a stop order. Bohlig v. First Nat. Bank in Wadena, 233 Minn. 523, 48 N.W. 2d 445 (1951), noted in 5 Okla. L. Rev. 475 (1952), and [1952] Wash. U.L.Q. 276. When the holder deposits the check to his account in the drawer bank, the entry on the depositor's passbook is "payment." W. A. White Brokerage Co. v. Cooperman, 207 Minn. 239, 290 N.W. 790 (1940). But see note 7 supra.

Branch banks are considered to be separate entities, so the drawer's right to countermand continues good until the branch upon which the check is drawn has paid. Dean v. Eastern Shore Trust Co., 159 Md. 213, 150 Atl. 797 (1930); Mullinax v. American Trust \& Banking Co., 189 Tenn. 220, 225 S.W. 2d 38 (1949).

Oral notice is sufficient, Hiroshima v. Bank of Italy, 78 Cal. App. 362, 248 Pac. 947 (1926); as is an order by telephone, Shude v. American State Bank, 263 Mich. 519, 248 N.W. 886 (1933); Third Nat. Bank in Nashville v. Carver, 31 Tenn. App. 520, 218 S.W. 2d 66 (1948), telegraph, Ozburn v. Corn Exchange Nat. Bank of Chicago, 208 IIl. App. 155 (1917), or to an officer outside the bank. Hewitt v. First Nat. Bank of San Angelo, 113 Tex. 100, 252 S.W. 161 (1923). Where a statute or deposit contract requires that a stop order be in writing, the bank waives its right to so insist by undertaking to act upon an oral order. Stamford State Bank v. Miles, 186 S.W. 2d 749 (Tex. Civ. App., 1945) (state statute); Bohlig v. First Nat. Bank in Wadena, 233 Minn. 523, 48 N.W. 2d 445 (1951) (contract of deposit). In the absence of statute, a stop order stays in force indefinitely, but forty jurisdictions now have statutes limiting original effect to six months. 3 Paton, Dig. Leg. Ops. 3,462-63 (1944) and Supp. (Dec., 1951).

The UCC would make several important changes and clarifications by providing in Section 4-303 that a stop order is effective "until but not after the bank has done any of the following:... (b) paid the item in cash; (c) settled the item by separate remittance for the particular item; (d) completed the process of posting the item to the indicated account of the drawer... or otherwise has evidenced by examination of such indicated account and by action its decision to pay the item; or (e) become liable for the item under Section 4-302 dealing with the payor bank's liability for late return of items." Section 4-403(2) provides: "An oral order is binding upon the bank only until the customer has had reasonable opportunity to send the bank a written confirmation if the bank requests such a confirmation. A written order is effective for only six months unless renewed in writing."

The selection of controlling facts in any such sections as these must necessarily be somewhat arbitrary. The codifiers have clearly resolved most differences among the courts in manners highly favorable to the banks. But in these matters definiteness seems, perhaps, the highest desideratum.

${ }^{15} \mathrm{~A}$ more subtle contract-type analysis of stop payment is presented by Professor Underhill Moore. The terms of the bargain are said to be "that the bank, in exchange for the deposit, will upon actual demand of the customer repay the full amount of the deposit and that the bank will, by honoring his checks, lend to the customer sums of money in amounts less than the amount owed but which do not aggregate more than the deposit." Moore, op. cit. supra note 9, at 818-19. In this analysis the presentment of a check is a condition precedent to the bank's obligation and a request for a loan (which is at once set off against the depositor's balance, if any). The presentment can be no request, of course, if the stop payment order has intervened.

${ }^{16}$ See Rest., Contracts $\$ \S 35,45-47$ (1932). 
the underlying transaction. ${ }^{17}$ When a check deposited for collection and forwarded to the payee bank is returned, marked "Payment Stopped," to the forwarding bank, its depositor must act to collect on the rejected instrument. He may look to the drawer or, if such there be, any unqualified indorser. If he is the payee or other holder "not in due course," 18 recovery will be had from the drawer if the only basis of the stop payment order is not such as to constitute a good defense. ${ }^{19}$ If a holder in due course, his much stronger position allows recovery free of the drawer's "personal" defenses. ${ }^{20}$ An inadvertent payment by the bank in such cases causes no real injury to its depositor. Nonetheless, because the bank is not permitted to charge the drawer's account after an unauthorized payment, ${ }^{21}$ and is seldom allowed to recover back from the person paid, ${ }^{22}$ the bank that slips up will often find that it has discharged a legitimate

${ }^{17}$ See, e.g., Usher v. A. S. Tucker Co., 217 Mass. 441, 105 N.E. 360 (1914); Gulf Refining Co. v. Bagby, 200 La. 258, 7 So. $2 d 903$ (1942).

${ }^{18}$ A "holder in due course" is defined in Section 52 of the NIIL. See annotations to Sections 52 and 53 , Brannan, op. cit. supra note 12 , at $674-721$. See also NIL $\$ 58$.

${ }^{19}$ As where the drawer stops payment because he "changes his mind" or where he is wrong in his suspicions as to fraud or failure of consideration. But where drawer can interpose any recognized equitable defense, a person with other than the rights of a holder in due course will not recover. 1 Joyce, Defenses to Commercial Paper $\$ 28$ (2d ed., 1924).

${ }^{20}$ But will usually not recover if the drawer can show a "real" defense, e.g., that the title is bad because of a forged or unauthorized material signature. For a discussion of the two categories of defenses, see Britton, Bills and Notes $\S \S 125-60$ (1943).

${ }^{21}$ Some writers contend that there now exists adequate support for a "rule" that the bank can charge the drawer's account after mistaken payment to a holder in due course. Brady, Bank Checks, 362-63 (2d ed., 1926). And see 3 Paton, Dig. Leg. Ops. 3464 (1944). Compare Michie, op. cit. supra note 5, at 476; 6 Zollman, Banks and Banking 107 (1936). The case most often cited in support of the asserted rule is Unaka Nat. Bank v. Butler, 113 Tenn. 574, 83 S.W. 655 (1904), where the payee of a check was not allowed recovery after the bank had paid, over a stop order, to a holder in due course. It is impossible on close reading of the case not to feel that the court became so interested in the subsidiary question of whether the holder of a blank endorsed check which had been lost, found by a stranger, and negotiated again could have a good title, that it failed to meet the central issue. At any rate the same court the next year clearly drained the Butler case of force as precedent by a directly contrary ruling in a case where suit was brought by the drawer. Pease \& Dwyer v. State Nat. Bank, 114 Tenn. 693, 88 S.W. 172 (1905).

The somewhat different question of whether there is support for the position that the bank may, after mistaken payment, be subrogated to the rights of the holder is discussed infra.

${ }_{22} \mathrm{~A}$ bank may almost never recover back payment made over a stop order to a holder in due course. National Bank of N.J. v. Berrall, 70 N.J.L. 757, 58 Atl. 189 (1904); Huffman v. Farmers' Nat. Bank, 10 S.W. 2d 753 (Tex. Civ. App., 1928); Rest., Restitution $\$ 33$ (1937). Contra: National Loan \& Exchange Bank v. Lachowitz, 131 S.C. 432, 128 S.E. 10 (1925). The same rule is most often applied when the question is recovery from the payee or other holder. Bank of Moultin v. Rankin, 222 Ala. 188, 131 So. 450 (1930); Albers v. Commercial Bank, 85 Mo. 173 (1884). And cf. National Commercial Bank \& Trust Co. v. Madison, 270 App. Div. 437,60 N.Y.S. $2 d 832$ (1946).

But where a check is paid by a bank as a result of the holder's fraud, deceit or misrepresentation, the payment may be recovered. Smith \& McCrorken, Inc. v. Chatham Phenix Nat. Bank \& Trust Co., 239 App. Div. 318, 267 N.Y. Supp. 153 (1933).

A few more recent decisions have allowed recovery from the payee under certain conditions. Murfreesboro Bank \& Trust Co. v. Travis, 190 Tenn. 429, 230 S.W. 2d 658 (1950) (recovery allowed where payee had given illegal consideration for the check): Union \& New Haven Trust 
debt of its depositor out of its own pocket, with no likelihood of recovery. This follows from the rule that after receipt of a stop order the bank has no more authority to pay a holder in due course or other rightful claimant than an offending payee. ${ }^{23}$ Thus, the present law imposes a far harsher sanction on the banks than that which has been suggested as desirable. ${ }^{24}$

Bankers, commentators, and the drafters of the proposed Uniform Commercial Code have each advanced proposals for mitigating the harshness of these consequences of Lord Ellenborough's rule. The most common proposals look toward (1) reducing the sanction for failure from liability for the full amount of the check to that of bearing only what has been designated above as the social cost of such failure-this involves making available to the payor bank a theory of recovery in appropriate cases from either the depositor or the party paid, or both; or (2) much more extreme, eliminating altogether or moderating the banks' duty to act on stop orders, or allowing the bank to "contract" for a lesser duty. Bankers have concentrated their attention on the second $;^{25}$ most writers approve the first; $;{ }^{26}$ the drafters of the Code provide both, and more. ${ }^{27}$

To reduce the sanction for failure to the measure of social cost, or an approximation thereof, several theories have been advanced.

(1) In a suit by the drawer, after his account is charged, the bank might be allowed to counterclaim as holder of the drawer's instrument as though undischarged. Section 119(1) of the NIL provides for discharge by payment "by or on behalf of the principal debtor." "[O]n behalf of" requires, it is argued, a properly authorized payor, and that after stop payment the bank does not qualify-thus that the instrument may be treated as undischarged. ${ }^{28}$ But Section 119(4) allows discharge "by any act which would discharge a simple contract for the

Co. v. Thompson, 134 Conn. 607, 59 A. 2d 727 (1948) (dictum that recovery might be allowed where payee has not changed position so as to be harmed by recovery). And cf. Central Nat. Bank v. International Sales Co., 8 Ohio App. 293, 91 N.E. $2 d 532$ (1950).

${ }^{23}$ See, e.g., Hiroshima v. Bank of Italy, 78 Cal. App. 362, 371, 248 Pac. 947, 950, 951 (1926). Exceptions to the rule are found only in a few of the jurisdictions in which it was formerly held that a drawer's check acted as a pro tanto assignment of his deposit; see note 12 supra.

24 See page 669 supra.

${ }^{25}$ See the form of stop payment "request" prepared by the Legal Department of the American Bankers' Association, reprinted at 3 Paton, Dig. Leg. Ops. 3,474-75 (1944), which, if signed by the depositor, would probably relieve the bank of liability in almost any eventuality.

${ }^{26}$ Britton, Bills and Notes $\$ 181$ (1943); 3 Paton, Dig. Leg. Ops. 3,478 (1944); Recovery against Depositor by Bank Paying Instrument after Stop Notice, 40 Harv. L. Rev. 110, 114 (1926); Recovery by Drawer against Bank for Payment of Check in Violation of Stop Payment Order, 45 Yale L.J. 1134, 1137 (1936).

${ }^{27}$ The relevant provisions of the UCC are discussed pages 674 and 676 infra.

${ }^{28}$ This analysis is suggested in the concurring opinion by Bijur, J., in K. \& K. Silk Trimming Co. v. Garfield Nat. Bank, 127 Misc. 27, 32, 215 N.Y. Supp. 269, 274 (S. Ct., 1926): "In the case before us, since the maker had forbidden the bank to pay the note, its acquisition thereof from the holder is not a discharge. ... I see no reason in law or equity why the defendent bank is not the owner, entitled to counterclaim the amount thereof..." 
payment of money," which seems to cover the act of a paying stranger. ${ }^{29}$ The argument further appears to ignore the real intent of the parties and the general understanding of bankers in the matter, as well as the rule that who is a party to an instrument is a question of form, to be determined by inspection..$^{30}$ So the theory, at best, is a shaky one.

(2) It has been argued ${ }^{31}$ that the bank should be allowed to defend against the drawer under a rule of quasi-contracts allowing recovery for a benefit conferred under mistake as to the existence of facts affecting the obligation to perform a contract. No stop payment case has been found which uses this reasoning.

(3) The most favored theory is that of subrogation, a doctrine which is said to suit any situation "where it is equitable that a person furnishing the money to pay a debt would be substituted for the creditor." ${ }^{32}$ As against the drawer, a bank would be allowed to benefit from any rights which would have been available to the holder or payee to whom the bank made erroneous payment; in suit for recovery from the payee or other holder, the bank could assert such rights as the drawer might have in respect to the underlying transaction. In this way, subrogation elegantly satisfies the sanction criterion suggested above: the real burden that stop payment seeks to minimize-finding, and getting and executing judgment against a party wrongfully paid-is clearly placed upon the bank, but there is no penalty for failure insofar as the failure causes no injury. No party to a check could then be harmed or improved in his ultimate position by a stop order, except as intended by the policy of the law. The incentive for speculative stop payment is removed. Strict liability, in conjunction with the subrogation remedy, efficiently transfers the risk of litigation from the drawer, who is no longer in a position to reduce it, to the bank, which can, and will automatically solve the social welfare-maximizing equaticn in attending to its own interests.

The symmetrical subrogation remedy is advanced in Section 4-407 of the Code. ${ }^{33}$ In promulgating it, the drafters have wisely adapted a powerful tocl of equity to a use for which it has been widely recommended, but seldom employed by the courts. ${ }^{34}$ The result should prove to be a considerable advance.

${ }^{29}$ See Rest., Contracts $\$ 421$ (1932).

31 Harvard L. Rev., op. cit. supra note 26.

${ }^{32}$ Sherman v. Yarbo Products Corp., 201 App. Div. 647, 194 N.Y. Supp. 705, 706 (1922).

${ }^{33}$ Such a remedy was included as early as 1934 in drafts prepared by Professor Roscoe Steffen of a Uniform Bank Collection Code. Fifth Tentative Draft $\$ 14$, Handbook of the National Conference of Commissioners on Uniform State Laws 172 (1934). This act was never promulgated to the legislatures. The earlier American Bankers' Association Collection Code, enacted by eighteen states, has no comparable provision.

34 The General Counsel of the American Bankers' Association expresses the opinion that "a bank would seem to be entitled to be subrogated to the rights of the drawer against the payee." But no cases are cited. 3 Paton, Dig. Leg. Ops. 3475, 3478 (1944). To support the statement that the bank may be subrogated to the rights of the payee against the drawer, Professor Britton cites only one case, and that of doubtful relevance. Britton, Bills and Notes $\S 181$ n. 5 (1943). 


\section{III}

The bankers have advanced a less elegant but highly effective remedy for the stop payment malaise-eliminate the stop payment duty altogether. This they have sought to do contractually by placing in passbooks and stop order forms clauses which exculpate the bank from liability in cases of payment "through inadvertence, accident, or oversight." ${ }^{35}$ Such clauses have now been tested in the courts of nine states..$^{36}$

In New York, Massachusetts, and Indiana, the clauses have been held valid. In Gaita v. Windsor Bank, ${ }^{37}$ the leading New York case, the court recognizes that the common law duty of the bank is absolute, and that a depositor may hold a bank to that duty, but allows "freedom of contract" where the depositor has signed away his right-the clause is not void as against public policy. The Massachusetts ${ }^{38}$ and Indiana ${ }^{39}$ courts agree.

In California, ${ }^{40}$ Ohio, ${ }^{41}$ and Pennsylvania ${ }^{42}$ the exculpatory clause cited is contrary to public policy, whether it appears in the original passbook contract or on stop order forms which a poorly advised depositor signs at a bank's behest. The highest Connecticut ${ }^{43}$ and New Jersey ${ }^{44}$ courts have also struck down such clauses in the cases coming before them, but on the grounds that where the clause is found in the stop order form the bank gives no consideration for the

${ }^{35}$ See note 25 supra.

${ }^{36}$ See, generally, Exculpation Clauses in Stop-Payment Orders, 6 Rutgers L. Rev. 577 (1952); Stipulation Relieving Bank from, or Limiting Its Liability for Disregard of, StopPayment Order, 1 A.L.R. 2d 1155 (1948).

${ }^{37} 251$ N.Y. 152, 167 N.E. 203 (1929). This decision reversed the older New York rule announced in Elder v. Franklin Nat. Bank, 25 Misc. 716, 55 N.Y. Supp. 576 (S. Ct., 1899), and Levine v. Bank of the U.S., 132 Misc. 130, 229 N.Y. Supp. 108 (N.Y. Munic. Ct., 1928). It has been followed in the subsequent decisions: Edwards v. National City Bank of N.Y., 150 Misc. 80, 269 N.Y. Supp. 637 (N.Y. Munic. Ct., 1934); Pyramid Musical Corp. v. Floral Park Bank, 268 App. Div. 783, 48 N.Y.S. 2d 866 (1944); Chase Nat. Bank v. Battat, 297 N.Y. 185, 78 N.E. 2d 465 (1948); Cortillion Fabrics Corp. v. National Safety Bank \& Trust Co. of N.Y., 193 Misc. 741, 84 N.Y.S. 2d 880 (S. Ct., 1949); In re Rousos' Will, 195 Misc. 959, 91 N.Y.S. 2d 551 (Surr. Ct., 1949).

38 Tremont Trust Co. v. Vurack, 235 Mass. 398, 126 N.E. 782 (1920).

${ }^{39}$ Hodnick v. Fidelity Trust Co., 96 Ind. App. 342, 183 N.E. 488 (1932).

${ }^{40}$ Hiroshima v. Bank of Italy, 78 Cal. App. 362, 248 Pac. 947 (1926); Grisinger v. Golden State Bank, 92 Cal. App. 443, 268 Pac. 425 (1928).

${ }^{41}$ Speroff v. First-Central Trust Co., 149 Ohio St. 415, 79 N.E. $2 d 119$ (1948), noted in 17 Fordham L. Rev. 268 (1948), 24 Notre Dame Lawyer 117 (1948), 9 Ohio St. L.J. 543 (1948), 34 Va. L. Rev. 834 (1948), 33 Minn. L. Rev. 179 (1949), and 18 U. of Cin. L. Rev. 105 (1949). This case overrules John H. Mahon Co. v. Huntington Nat. Bank, 62 Ohio App. 261, 23 N.E. 2d 638 (1939).

42 Thomas v. First Nat. Bank of Scranton, 126 L.I. 203 (Pa., 1952), noted in 25 Temp. L.Q. 486 (1952), and 2 Catholic U.L. Rev. 128 (1952). Cf. Cohen v. Bank of Philadelphia, 69 Pa. Super. 48 (1917).

43 Calamita v. Tradesmen's Nat. Bank, 135 Conn. 326, 64 A. 2d 46 (1949), noted in 25 N.Y.U.L. Rev. 419 (1950).

44 Reinhardt v. Passaic-Clifton Nat. Bank \& Trust Co., 16 N.J. Super. 430, 84 A. 2d 741 (1951), noted in 27 N.Y.U.L. Rev. 345 (1952). 
depositor's waiver of his right. And in South Carolina, ${ }^{45}$ the Supreme Court found for the depositor without passing upon the clause by holding that the burden of proof that the failure was "mere inadvertence or oversight" was on the bank when it pleaded the clause in bar, and had not been met.

The most persuasive opinion on the subject is also the most recent-that of the Superior Court of New Jersey in Reinhardt v. Passaic-Clifton National Bank Trust Company. ${ }^{46}$ The plaintiff had signed a stop order form provided by the bank containing a small-print exculpation clause. A notice to the clerks was duly recorded on the jacket over the ledger sheet of the plaintiff's account, but the check was paid. Reviewing all the cases, the court decided on the narrower ground of failure of consideration for the release, recognizing that the liability which the bank sought to avoid was "not dependent on the proof that the bank failed to exercise reasonable care," and suggesting stronger medicine, if need be, in the future:

Perhaps the bank and its depositor may, in legal contemplation, be viewed as having equal bargaining power and freedom of contract, although full recognition of modern day realities may well suggest a contrary conclusion. ... Nevertheless, the bank has been entrusted with an important franchise to serve the public and has, from time to time, received broad legislative protection.... Under the circumstances might it not be appropriate to apply to banks the legal doctrine which has deprived quasi-public enterprises such as utilities of the power to require release clauses comparable to that used by the defendant? ${ }^{37}$

In avoiding the effect of the clause, the California and Ohio courts have, on the other hand, fallen into an easy error. They throw out the clause as contravening public policy against "escaping liability for one's own negligence by contract." ${ }^{48}$ The exculpatory clauses, of course, do seek to do this, but they also attempt more - to contract away the greater duty required by the traditional strict liability. These cases are thus made to turn on a weaker ratio decidendi than was available; more important, their language indicates a confusion as to the traditional stop payment rule. These misplaced words have found their way into the Uniform Commercial Code, Section 4-103 providing:

The effect of this Article may be varied by agreement except that no agreement can disclaim a bank's responsibility or limit the measure of damages for its own lack of good faith or failure to exercise due care. (Emphasis added.)

This section, in effect, reduces the bank's duty from its traditional level to the lower requirement of "good faith" and "due care." Furthermore, under the Code's rule, the depositor's simple cause of action in pleading payment over a stop order ${ }^{49}$ becomes one in which it is necessary to show that the operation of the bank's check-stopping machinery, at the fateful moment, was not on a par

${ }_{45}$ Carroll v. South Carolina Nat. Bank, 211 S.C. 406, 45 S.E. 2 d 729 (1947).

4816 N.J. Super. 430, 84 A. 2d 741 (1951).

47 Ibid., at 436 and 744.

${ }^{48}$ Hiroshima v. Bank of Italy, 78 Cal. App. 362, 378, 248 Pac. 947,953 (1926).

49 The necessary allegations in an action by a drawer on failure of stop payment are (1) that plaintiff had money on deposit, (2) that the check was issued, (3) that a stop payment order was 
with the standard and reasonable practice set by the banking community, a task which a depositor is in a singularly poor position to undertake, regardless of the facts of the case. ${ }^{50}$

Perhaps some courts, faced with the Code's provision, might follow the lead of the South Carolina decision, ${ }^{51}$ salvaging in part the stop payment duty by - placing the burden of proof on the bank as to absence of negligence, or by directing the jury's attention to the inferences which arise from a situation when the doctrine of res ipsa loquitur is appropriate. ${ }^{52}$

But even so, it is difficult to understand the inclusion of this provision in the same Article which recognizes the only major flaw in the present stop payment rules, and handsomely corrects its unreasonable harshness on payor banks by allowing subrogation. It would seem more reasonable for the Code to have chosen the course of efficiency and simplicity by making explicit the public policy which for more than a century has defined stop payment as a service to the business community which a bank must perform, if it is to be done at all, because there is no one else who can.

given, (4) that the check was nevertheless paid, and (5) that the money was demanded from the drawee, which demand was refused. 6 Zollman, Banks and Banking \$ 3711 (1936).

The UCC provides specifically only that: "The burden of establishing the fact and amount of loss resulting from the payment of an item contrary to a binding stop order is on the customer." UCC \$4-403(3). The critical question-who bears the burden of proof as to "due care"-is not treated. The usual rule would appear to apply. See note 51 infra.

${ }^{50} \mathrm{~A}$ somewhat comparable situation is that in which a depositor claims loss of property from a bank safe deposit box. In spite of the ease of perjury in the deposit box cases, the courts have often, although not always, ruled that there is a presumption of negligence on the part of the depositary arising from the depositor's testimony that the property was placed in the box and never returned. See e.g., Veihelmann v. Manufacturers' Safe Deposit Co., 303 N.Y. 526, 104 N.E. 2d 888 (1952). The outcome may depend on the form of the depositor's complaint. See Liability for Loss of Contents of Safe-Deposit Box, 133 A.L.R. 279, 291 (1941); Ability of Banks to Limit Liability by Contract, 26 Notre Dame Lawyer 476 (1951).

${ }^{51}$ Carroll v. South Carolina Nat. Bank, 211 S.C. 406, 412, 45 S.E. 2d 729, 731 (1947), where the court said, "[W]e think the admitted facts show a prima facie case of liability and the burden of producing evidence to overcome appellant's prima facie case by showing that it acted in good faith and used all reasonable efforts to comply with the instructions given rested on respondent. ... Appellant would not be expected to know these facts." And see Chicago Savings Bank v. Block, $126 \mathrm{IIl}$. App. 128, (1906). Apparently this rule is followed in Pennsylvania. Thomas v. First Nat. Bank of Scranton, 126 L.I. 203 (Pa., 1952). But the general rule is that the full burden of proof must be sustained by the drawer. 9 C.J.S., Banks and Banking $\$ 411$ (1938).

${ }^{52}$ See Prosser, Torts $\$ \$ 43,44$ (1941).

\section{DEFAMATION IMMUNITY FOR EXECUTIVE OFFICERS}

The increasing publicity afforded the workings of government and the current concern over subversive activity ${ }^{1}$ present in an acute form the familiar

\footnotetext{
1 For other examples of the impact of the fear of subversion on traditional areas of the law, see Communists and the Right to Bail, 20 Univ. Chi. L. Rev. 330 (1953); Defamation Immunity, 18 Univ. Chi. L. Rev. 591 (1951).
} 